\title{
Land Subsidence Prediction in Central Plain of Thailand
}

\author{
Piyakarn Teartisup and Prapeut Kerdsueb
}

\begin{abstract}
The aim of this research was to analyze risk areas of land subsidence. Risk factors were selected from related research on the problem of land subsidence. There were six factors selected: geological, hydrogeological, number of wells, groundwater used, land use and amount of population. The factors were analyzed by weighting and rating scores from twelve governmental officers from concerned agencies. The total score of each factor was employed to assess risk area of land subsidence by GIS and PCA method. The output in this study is a map of risk area of land subsidence in Nakhon Pathom Province, representative central plain area. In this study, the risk area of land subsidence was classified into 3 levels. Most of the land consisted of areas at a moderate risk of subsidence and these areas were scattered throughout the study area, covering $1,905.93 \mathrm{~km}^{2}$, while a high level to at risk areas was found in parts of the west and south of the study area, covering $251.02 \mathrm{~km}^{2}$. The low level of land subsidence risk covered the least area, at only $14 \mathrm{~km}^{2}$, mainly in the northwestern and eastern parts of the study area. Furthermore, the results showed land subsidence is most heavily influenced by excessive utilization of groundwater. The second most influential factor is the number of wells. A comparison of bench marks from the Royal Thai Survey Department, ground checks of the real situation and the assessments made in this study showed all.
\end{abstract}

Index Terms-Land subsidence, central plain of Thailand, GIS, PCA.

\section{INTRODUCTION}

A number of phenomenon factors account for land subsidence in has been attributed to: 1) loading of a land surface, 2) vibrations at or near the land surface, 3) compaction due to irrigation, 4) solution due to irrigation, 5) drying and shrinkage of deposits, 6) oxidation of organic materials, 7) decline of the water table, 8) decline of artesian pressure in water sands, 9) decline of pressure in oil zones due to the removal of oil and gas, and 10) tectonic movement [1]. Spatial variation in geological, ground water, geomorphological, soil and vegetation characteristics can distribute to diversity of landform [2] The nature and intensity of land subsidence are therefore likely to be highly dependent on the physical context (geological, hydrogeological, well location, groundwater use, land use) and amount of population and also the level of problem varies by difference factors [3].

Thailand, land subsidence is crisis problems which occur to central plain region as especially economic area [4]. The major cause of this problem comes from over pumping groundwater, since people have problems with lack of water supply in household and industrial sectors [5] [6]. Demand

Manuscript received October 20, 2012; revised January 26, 2013.

The authors are with the Faculty of Environment and Natural Resource Studies, Mahidol University, Thailand (e-mail: piyakarn.tea@mahidol.ac.th, peat2u@yahoo.com). for water to groundwater pumping increases every year, this event resulted in the land subsidence [7]. Central Plain of Thailand got the land subsidence as high rate around $10 \mathrm{~cm}$. per year [8]. Nakhon Pathom, one main province in the central plain of Thailand with the total area of $2,170.96 \mathrm{~km}^{2}$. Nakhon Pathom province is divided into 7 Districts such as Mueang, Khamphaengsaen, Dontum, Nakhon Chai Si, Bang Len, Sam Phran and Putthamonthon. In order to keep central plain representation, this paper selects Nakhon Pathom, province study area. Based on Geographic Information System (GIS) and collected data, the effected factors of land subsidence are discussed combining with Principal Components Analysis (PCA) method.

\section{Methodology}

\section{A. Choosing Factors}

Considering the six factors including geological, hydrogeological, amount of well, groundwater use, land use and amount of population [9]-[11]. In 2005, we work in the field to survey the overall condition of studied area exploring the bench mark of Royal Thai survey Dept. and exiting land use and wells characteristic. The other data are collected by literature, statistical annual and referring data.

\section{B. Data Analysis}

The data was analyzed by GIS [12] and PCA method. We use questionnaire for asking the 12 environmental officers (from Dept. of Groundwater Resources and Dept. of Mineral Resources). They were generated weighting score by comparing on importance of each factor that appropriate and importance on prediction the risk of land subsidence. At the same time the environmental officers analyzed each factor first and mark the score on the range from 1-5 according to the suitable factors within the same group. GIS and PCA method combined together by below equation (1)

$$
S=W_{1} R_{1}+W_{2} R_{2}+W_{3} R_{3} \ldots W_{\mathrm{n}} R_{\mathrm{n}}
$$

where $\quad S=$ risk level of land subsidence

$W_{1}$ to $W_{\mathrm{n}}=$ weighting of each factor

$R_{1}$ to $R_{\mathrm{n}}=$ score of sub factor from 1 to $\mathrm{n}$

1 to $n=$ effective factors

\section{RESUlTS}

Quaternary sediment of tidal-dominated deposits, flood plain aquifers, lower than 20 wells, lower than $300 \mathrm{~m} 3 / \mathrm{hr}$. of groundwater Use, Agriculture area and lower than 7,000 amount of people were the majority characteristics of the area. The detail was shown in Table I.

The approval and weighting values gained from these persons would be analyzed further for finding forecasting model for risk of land subsidence. Frequency of weighting 
and rating values is a little bit difference among officers from concerned agencies but their opinions seem in the same way. The result was shown in Table II.

TABLE I: THE CHARACTERISTICS OF THE STUDY AREA

\begin{tabular}{|c|c|c|}
\hline \multirow{2}{*}{ Characteristics } & \multicolumn{2}{|c|}{ Area } \\
\hline & $\mathrm{km} 2$ & $\%$ \\
\hline \multicolumn{3}{|l|}{ Geology and water body } \\
\hline $\begin{array}{l}\text { - Quaternary sediment of tidal-dominated } \\
\text { deposits }\end{array}$ & $1,914.04$ & 88.17 \\
\hline - $\quad$ Alluvial fan & 247.09 & 11.38 \\
\hline - Water resource & 9.82 & 0.45 \\
\hline \multicolumn{3}{|l|}{ Hydrogeology } \\
\hline - $\quad$ Flood plain aquifers & $1,635.78$ & 75.35 \\
\hline - $\quad$ Low terrace aquifers & 535.18 & 24.65 \\
\hline \multicolumn{3}{|l|}{ Number of Wells } \\
\hline - $\quad<20$ wells & $1,120.77$ & 51.63 \\
\hline - $\quad 20-40$ wells & 808.16 & 37.23 \\
\hline - $\quad>40$ wells & 242.03 & 11.15 \\
\hline \multicolumn{3}{|l|}{ Groundwater Use } \\
\hline - $\quad<300 \mathrm{~m} 3 / \mathrm{hr}$ & $1,056.08$ & 48.65 \\
\hline - $\quad 300-600 \mathrm{~m} 3 / \mathrm{hr}$ & 867.50 & 39.96 \\
\hline - $\quad>600 \mathrm{~m} 3 / \mathrm{hr}$ & 247.38 & 11.39 \\
\hline \multicolumn{3}{|l|}{ Land Use } \\
\hline - $\quad$ Industry & 9.61 & 0.44 \\
\hline - $\quad$ Agriculture & $1,712.85$ & 78.90 \\
\hline - Urban and Build up Land & 375.86 & 17.31 \\
\hline - Water resources & 32.84 & 1.51 \\
\hline - $\quad$ Miscellaneous & 39.64 & 1.83 \\
\hline \multicolumn{3}{|l|}{ Amount of population } \\
\hline - $\quad<7,000$ people & $1,210.26$ & 55.75 \\
\hline - $\quad 7,000-13,000$ people & 912.02 & 42.01 \\
\hline - $\quad>13,000$ people & 48.67 & 2.24 \\
\hline
\end{tabular}

TABLE II: WeIGHTING AND RATING SCORE OF LAND SUBSIDENCE

\begin{tabular}{|c|c|c|c|}
\hline Factors & Criterion & Weighting & Rating \\
\hline \multirow{2}{*}{ 1. Geology } & $\begin{array}{l}\text { Quaternary sediment of } \\
\text { tidal-dominated deposits, Qa }\end{array}$ & \multirow{2}{*}{3} & 4 \\
\hline & Alluvial fan, Qt & & 1 \\
\hline \multirow{2}{*}{$\begin{array}{l}2 . \\
\text { Hydrogeology }\end{array}$} & $\begin{array}{l}\text { Flood plain aquifers of } \\
\text { Quaternary age, Qfd }\end{array}$ & \multirow{2}{*}{3} & 3 \\
\hline & $\begin{array}{l}\text { Low terrace aquifers of } \\
\text { Quaternary age, Qlt }\end{array}$ & & 3 \\
\hline \multirow{3}{*}{ 3. Wells } & $<20$ wells & \multirow{3}{*}{4} & 1 \\
\hline & 20-40 wells & & 2 \\
\hline & $>40$ wells & & 4 \\
\hline \multirow[t]{3}{*}{$\begin{array}{l}\text { 4. Groundwater } \\
\text { Use }\end{array}$} & $<300 \mathrm{~m} 3 / \mathrm{hr}$ & 5 & 2 \\
\hline & $300-600 \mathrm{~m} 3 / \mathrm{hr}$ & & 3 \\
\hline & $>600 \mathrm{~m} 3 / \mathrm{hr}$ & & 5 \\
\hline
\end{tabular}

TABLE II: WEIGHTING AND RATING SCORE OF LAND SUBSIDENCE (CONTS)

\begin{tabular}{|c|c|c|c|}
\hline Factors & Criterion & Weighting & Rating \\
\hline \multirow{5}{*}{ 5. Land Use } & Industry & \multirow{5}{*}{3} & 5 \\
\hline & Agriculture & & 1 \\
\hline & Urban and Build up Land & & 2 \\
\hline & Water resources & & 1 \\
\hline & Miscellaneous & & 1 \\
\hline \multirow{3}{*}{ 6. Population } & $<7,000$ people & \multirow{3}{*}{3} & 1 \\
\hline & $7,000-13,000$ people & & 2 \\
\hline & $>13,000$ people & & 3 \\
\hline
\end{tabular}

The risk area of land subsidence was classified in 3 levels using the total scores of these factors. The three levels included high risk of land subsidence, moderate risk of land subsidence and low risk of land subsidence. The majority of the area $(87.79 \%)$ was covered by moderate risk area of land subsidence and covered most of the area of study area. The results were shown in Table III and Fig. 1.

TABLE III: THE RISK AREA OF LAND SUBSIDENCE

\begin{tabular}{llcc}
\hline \multirow{2}{*}{ Rick level } & \multicolumn{1}{c}{ District } & \multicolumn{2}{c}{ Area } \\
\cline { 3 - 4 } Low & Khamphaengsaen & 10.42 & Percent \\
\hline \multirow{4}{*}{ Nakhon Chai Si } & 1.76 & 0.66 \\
& Bang Len & 1.38 & 0.24 \\
& Sam Phran & 0.45 & 0.2 \\
& Total & 14.00 & 0.65 \\
& Bang Len & 573.29 & 99.72 \\
& Mueang & 342.37 & 82.62 \\
& Khamphaengsaen & 317.60 & 68.39 \\
& Nakhon Chai Si & 250.65 & 94.39 \\
& Sam Phran & 197.86 & 87.28 \\
& Dontum & 152.39 & 100.00 \\
& Phutthamonthon & 71.76 & 99.63 \\
High & Total & $1,905.93$ & 87.79 \\
& Khamphaengsaen & 136.4 & 29.37 \\
& Mueang & 72.57 & 17.51 \\
& Sam Phran & 28.39 & 12.52 \\
& Nakhon Chai Si & 13.14 & 4.95 \\
& Phutthamonthon & 0.27 & 0.37 \\
& Bang Len & 0.26 & 0.05 \\
& Total & 251.02 & 11.56 \\
\hline
\end{tabular}

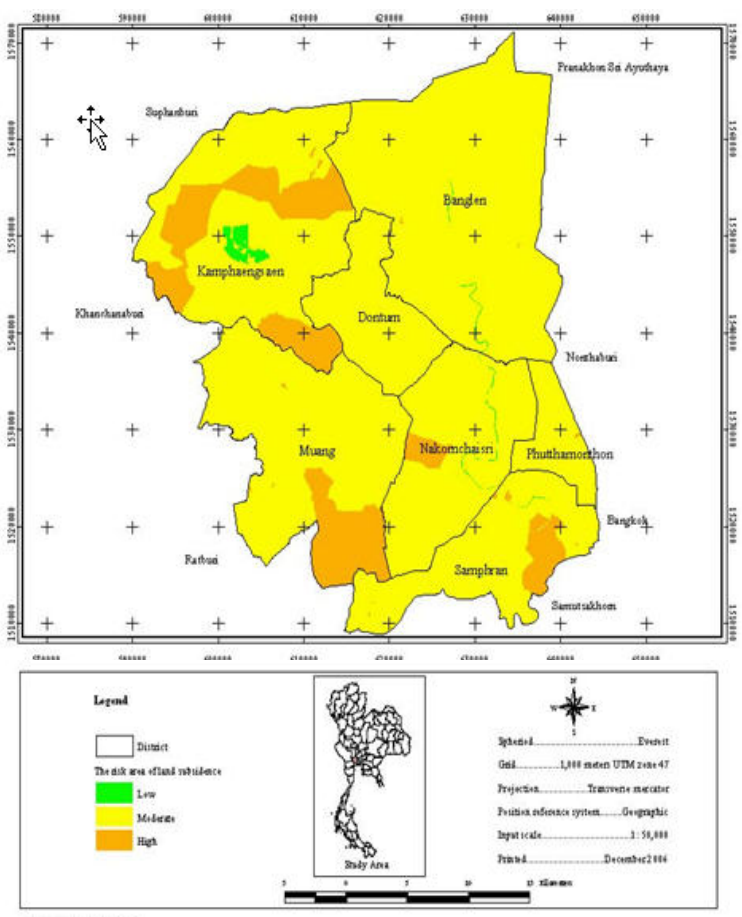

Fig. 1. The risk area of land subsidence

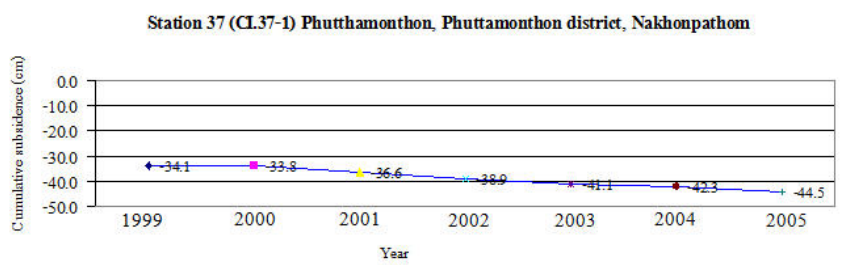




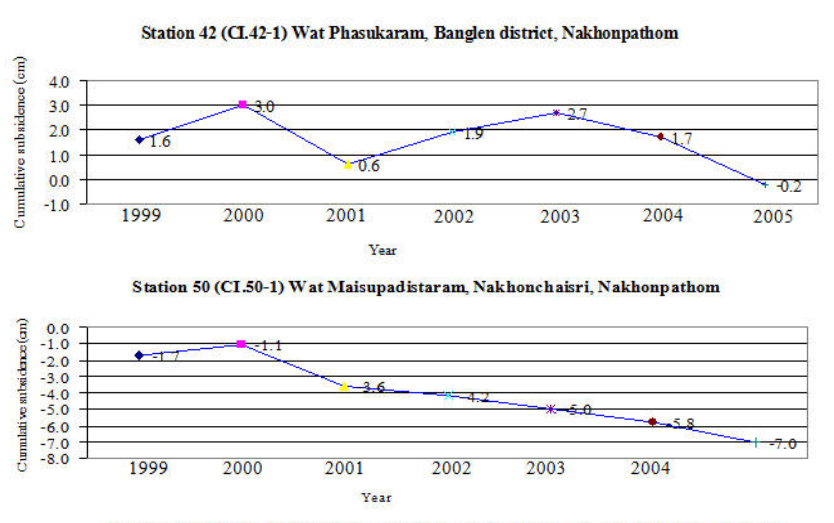

Station 52 (CI.52-1) Wat Jindaram School, Samphran district, Nakhonpathom
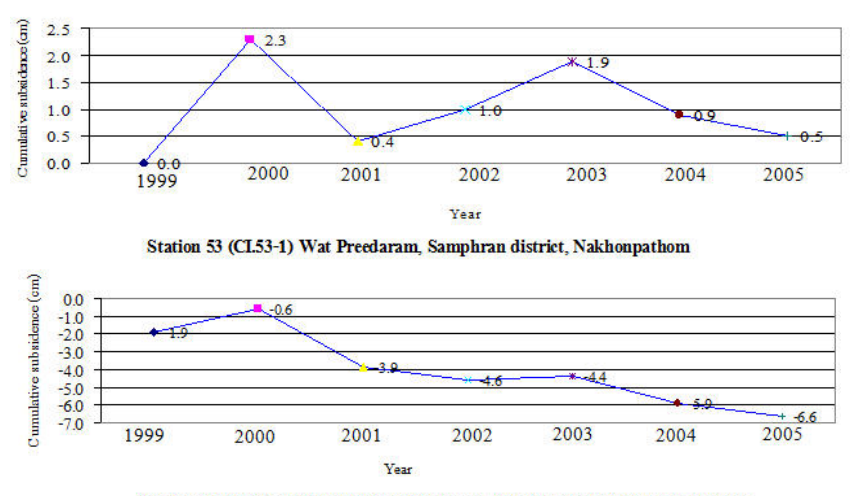

Station 50 (CI.50-1) Wat Maisupad istaram, Nakhonch aisri, Nakhonp athom

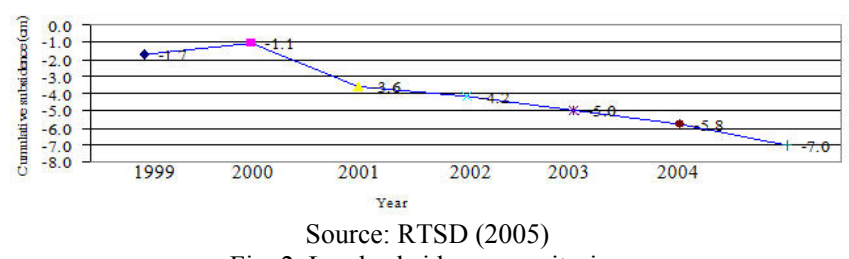

Fig. 2. Land subsidence monitoring

The results from analyze reveal: 1) most area was moderate risk area of land subsidence scattered throughout the study area, covering $1,905.93 \mathrm{~km} 2(87.79 \%)$. Most of moderate risk area of land subsidence covers Bang Len district and parts of Mueang, Khamphaengsaen, Nakhon Chai $\mathrm{Si}$ and Sam Phran districts, 2) the high risk area of land subsidence covers $251.02 \mathrm{~km} 2(11.56 \%)$ and is often found in parts of the west and south of the study area. Most of the high risk area of land subsidence covers Kamphaeng Saen and parts of Mueang, Sam Phran, Nakhon Chai Si, Phutthamonthon and Bang Len districts, 3) the low risk area of land subsidence covered the least area, at only $14 \mathrm{~km} 2$ $(0.65 \%)$, mainly in northwestern and eastern parts of the study area, especially Kamphaeng Saen and parts of Nakhon Chai Si, Bang Len and Sam Phran districts.

The risk area map of land subsidence in Nakhon Pathom province from this study was presented in the form of a potential map of subsiding. A comparison of bench marks from the Royal Thai Survey Department, ground checked of the real situation and the assessments made in this study showed the output from three sources were in the same direction. A map that shows risk area of land subsidence in Nakhon Pathom province from this study was presented in the form of a potential map of subsiding. The comparison of bench marks from the Royal Thai Survey Department, ground checks of the real situation and the assessments made in this study showed the output from three sources were in the same direction.

\section{CONCLUSIONS}

Based on GIS and PCA method, it was shown that land subsidence has a close relationship with groundwater use and expander of amount of well. To roundly determine the principle factors inducing land subsidence, PCA are utilized to deal with the six factors including geological, hydrogeological, amount of well, groundwater use, land use and amount of population. They were moderate risk area of land subsidence scattered throughout the study area, covering $87.79 \%$. Most of moderate risk area of land subsidence covers Bang Len district and parts of Mueang district, Khamphaengsaen district. And result shows that influences of moderate risk were Urban and Build up Land and agricultural areas.

\section{ACKNOWLEDGMENT}

Thank you all the environmental officers from Dept. of Groundwater Resources and Dept. of Mineral Resources for the opinions. Ms. Narisa Saejeng was thanked for help with data collection and filed work.

\section{REFERENCES}

[1] J. F. Poland and G. H. Davis, Subsidence of the land surface in the Tulare-Wasco, Delano and Los Banos-Kettleman City areas, San Joaquin Valley, American Geophysical Union Trans, California, p. 287-296, 1956.

[2] J. P. R.Gooderham, L. A. Barmuta, and P. E. Davies, "Upstream heterogeneous zones: small stream systems structured by a lack of competence?" Journal of the North American Benthological Society, vol. 26, no. 3, pp. 365-374, 2007.

[3] DGR, "Effect of Groundwater Recharge on Land Subsidence and Groundwater Quality by Using Mathematical Model Study,” Draft Final Report, Bangkok, Kasetsart University, 2004.

[4] T. Akaki, "Some Land Subsidence Experiences in Japan and their Relevance to Subsidence in Bangkok," Thailand. 1979.

[5] W. Maolanon, "Factor of Land Subsidence on Samutsakhon Province," Master's Thesis of Science, Bangkok: Ramkamhaeng University, 1994.

[6] Survey on elevation of monitoring wells and subsidence points in Bangkok and surrounding area, Bangkok: Division of Survey, Department of Mineral Resources, 1998.

[7] P. Pathomboon, "Geographic Information System for Land Subsidence in Beung Kum Bangkok," Master's Thesis of Science, Bangkok: Chulalongkorn University, 2001.

[8] Natural Resource and environment Database in Nakhon Pathom, Department of Environmental Quality Promotion, Bangkok. Ministry of Natural Resource and Environment, 2004.

[9] G. N. Paudyal, Land subsidence: Impact on water resource planning, Bangkok: AIT, 1984.

[10] N. A. Duc, "Updating and analysis of Bangkok land subsidence caused by deep well pumping with emphasis on shallow soil settlement," Bangkok: AIT, 1999.

[11] Handbook of Groundwater Use Map in Nakhon Pathom, Bangkok. GMT cooperation ltd., 2004.

[12] P. A. Burrough, Principal of Geographic Information System for Land Resources Assessment, Oxford: Clarendon Press, 1986.

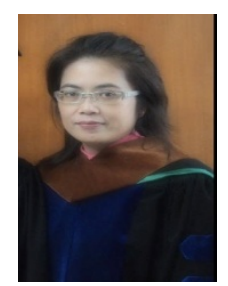

Piyakarn Teartisup was born in 1967, Bangkok, Thailand. She got Ph.D from Kasetsat University in Forestry-Watershed Management and as a lecturer at Faculty of Environment and Natural Resource Studies, Mahidol University more over 15 years. In 2010, she has attended the training course on traditional forest knowledge held within the framework of XXIII IUFRO world congress in Republic of Korea. 